\title{
The Urgency of Management Functions in Improving the Quality of Education Services in Public Senior High Schools 1 Biak
}

\author{
Hermanu Iriawan, Wilda Sasmita, Muhammad Rusdi \\ Institut Ilmu Sosial dan Ilmu Politik (IISIP) YAPIS Biak Numfor, Biak Papua Barat, \\ Indonesia \\ Email: wildasas26@gmail.com
}

(Received: September10-2019; revised: Oktober 18-2019; published: December 31-2019)

\begin{abstract}
The quality of education services is a "fixed price" in realizing the quality of education by the objectives of the Republic of Indonesia. This study aims to determine the importance of management functions in improving the quality of education in the Public Senior High School (SMAN) 1 Biak. A qualitative research approach carried out at Biak 1 High School located in Biak Numfor Regency, West Papua. Data collection techniques are done through observation, interviews, literature study, and documentation. The data analysis technique is done descriptively in compiling information systematically, from existing data so that it is easily understood and interpreted. The results showed that the management functions applied in the Biak Kota 1 High School were: planning, organizing, directing, coordinating, and controlling. In the process seen based on the condition of the school in implementing management functions. These results provide good results from every aspect of the implementation of management functions.
\end{abstract}

Keywords: Management Functions, Service Quality, Education.

\section{INTRODUCTION}

Improving the quality of educational services is a process that is integrated with the process of improving the quality of quality human resources through, among others, quality education services, curriculum development, and evaluation systems, improvement of educational facilities, development and procurement of teaching materials, as well as training for teachers and other education personnel. But in reality, these efforts have not been significant enough in improving the quality of Education (Akib, Guntur, \& Salam, 2016; MS Saggaf, Akib, Salam, Baharuddin, \& Kasmita, 2018; MS Saggaf, Aras, et al., 2018; MS Saggaf \& Greetings, 2017).

The quality of education services will be affected by the extent to which the institution can manage all potentials ranging from education staff optimally, students, learning processes, educational facilities, finance and including its relationship with the community (MS Saggaf, Nasriyah, Salam, \& Wirawan, 2018; MS Saggaf, Greetings, \& Rifka, 2017). On this occasion, educational institutions must be able to change the new paradigm of education to be more oriented to the quality of all activities in it. The form of the activity itself is an effort developed in improving the quality of Education (Amanda, Salam, \& Saggaf, 2017).

In realizing a quality education service, of course, good management is needed. Good management certainly refers to the management functions themselves, where the intended 
336 Jurnal Ilmiah Ilmu Administrasi Publik: Jurnal Pemikiran dan Penelitian Administrasi Publik

Volume 9 Number 2, July- December 2019. Page 335-344

functions are none other than POCCC. Management must be applied to organize teaching and learning activities because by applying management aspects such as planning, organizing, commanding, coordinating, controlling (S. Saggaf, Salam, Kahar, \& Akib, 2014; Terry \& Franklin, 1968).

Planning function, namely as a rationale for the objectives and the preparation of steps that will be used to achieve the objectives. Planning means preparing all needs, taking into account carefully what are the obstacles, and formulating the implementation of activities aimed at achieving goals. Organizing function is a way to gather people and place them according to their abilities and expertise in the work that has been planned. Commanding can be carried out to provide direction to all workers so that they want to cooperate and can work effectively in achieving a company's goals. Coordinating function is the integration, integration, synchronization of the efforts of group members to provide unity of action in pursuit of common goals. Controlling (Control function) is to oversee whether the movement of this organization is by the plan or not as well as overseeing the use of resources in the organization so that it can be used effectively and efficiently without anyone deviating from the plan.

The Public Senior High School (SMAN) 1 Biak is one of the favorite high schools in the city of Biak. Every year the number of students registering increases, therefore a management function is needed to improve the quality of education services at SMAN 1 Biak. In this case, neat management can support the achievement of educational goals. Good management determines the pros and cons of learning, how a teacher uses appropriate methods, the provision of adequate learning tools, and a conducive classroom atmosphere when teaching and learning.

But from the observations of researchers on the object under study, the management functions that have been carried out at SMAN 1 Biak still need to be addressed, where the application of existing regulations and services at school is good, but there are still some students who do not comply and understand about these regulations, as well as discipline and supervision of students who are still not optimal so that the things that are not desired by the school are often repeated, addressing these issues certainly cannot be allowed to continue. Under these conditions, the school should consider the importance of the management function in improving the quality of education services at SMAN 1 Biak.

\section{METHOD}

By the title of the study, this research is located in the Public Senior High School (SMAN) 1 Biak. SMAN 1 Biak is a superior high school located in Biak Numfor Regency, which is located on Jalan Sorido Yafdas No. 01 Biak. This research is qualitative. Called qualitative research, because the main data source of this research is in the form of words and actions of the people observed or interviewed. Researchers use qualitative research proposed by Creswell \& Poth (2018) that, qualitative research is research that intends to understand phenomena about what is experienced by research subjects, for example, behavior, perception, motivation, action, etc. holistically, and in a way described in the form of words and language, in a natural context and by utilizing various scientific methods.

In this study, the types and sources of data used are Primary Data that is data obtained directly from the object under study. According to Creswell \& Creswell (2017) that "Primary sources are data sources that directly provide data to data collectors." Primary data obtained 
from informant sources, namely individuals or individuals such as the results of interviews conducted by researchers. While secondary data according to Creswell \& Clark (2017) are "Data sources that do not directly provide data to data collectors, for example through other people or documents". This data is used to support the primary information that has been obtained, namely from library materials, literature, previous research, books, and so forth.

The data source is the most urgent thing in the research process, because the data source is a major component that makes it a source of information so that it can describe the results of a study. Data sources in this study include: a) Principal of SMAN 1 Biak, b) Teaching Staff, namely Teachers, are the main information as sources of data in this study with the consideration that the teacher is the central figure as the executor in the learning process at school. The teacher referred to by the author as a source of data in this study is a teacher in SMAN 1 Biak, c) Administrative staff is an organization in carrying out its activities can not be separated from the administrative field, so it is needed in the field of administration. The field of administration has the task of collecting, processing, and storing data, filing or documenting data needed by an organization. Administrative tasks are not only in writing but also in terms of finance, staffing, and even equipment. School administration activities are tasks that involve the management of letters and compilation of school data/statistics, d) students are people who want to gain knowledge, skills, experience and good personality as a provision of life. The main target of improving the quality of education is students so that it is expected that learning methods can increase interest in learning.

Data collection is an important activity for research activities because data collection can determine the success or failure of a study. So in the selection of data collection techniques must be careful. Data collection techniques used in this study are: a) observation, b) interviews, c) literature study, d) documentation. Data analysis, according to Bogdan in Sugiyono (2009: 244) is the process of systematically searching and compiling data obtained from interviews, field notes and other materials so that they can be easily understood, and their findings can be shared with others.

Based on the qualitative data obtained, the data analysis technique used is descriptive, which is a technique that describes data with words or sentences separated by category to obtain conclusions. In practice, data analysis is open. Said to be open because it is open to changes, improvements, and improvements based on new data entered.

\section{RESULT AND DISCUSSION}

In general, the notion of management is the science and art of planning, organizing, mobilizing and controlling the efforts of the members of the organization and the use of organizational resources to achieve the goals set previously. Management has the activities of leading, managing, managing, controlling, and developing (S. Saggaf et al., 2014; Salam, 2015; Salam, Rosdiana, Suarlin, \& Akib, 2014). Management can be said as an art. Management is the art of completing work through collaboration with others. The art of management consists of the ability to see totality in separate parts of a unified picture of the vision. The art of management includes the vision's communication skills. The aspects of leadership planning, communication and decision making regarding the human element on how to use an art management approach.

Quality is something that is considered one of the important parts because quality shows the superiority of a product when compared to other products. Quality improvement is the business of every institution producing goods but also service products. Efforts in improving the 
338 Jurnal Ilmiah Ilmu Administrasi Publik: Jurnal Pemikiran dan Penelitian Administrasi Publik

Volume 9 Number 2, July- December 2019. Page 335-344

quality of education are issues that will continue to be a topic of discussion in education management. Quality is essential as part of the education process. The learning process is the goal of educational organizations. The quality of education is the quality of graduates and services that satisfy parties related to education. Quality of graduates related to graduates with good grades (cognitive, affective, and psychomotor) are accepted to continue to a higher level of quality and have a good personality. While the quality of services related to activities serving the needs of students, teachers, and employees as well as the community appropriately and precisely so that all were satisfied with the services provided by the school.

Improving the quality of education is an effort that must be pursued continuously so that expectations for quality and relevant education can be achieved. Quality education is the hope and demand of all education stakeholders. Everyone will naturally prefer knowledge of institutions that have good quality. On this basis, schools / educational institutions must be able to provide good service and quality so as not to be left behind and be able to compete with other educational institutions.

The importance of management in organizing an organization is necessary, as well as in management education is important. Institutions/companies engaged in the management of goods need good management. Educational institutions are institutions that manage people and aim to create quality human beings, of course this requires more extra thought than institutions managing goods. To improve the quality of education needs to be seen from many sides. Many education experts have expressed their opinions on the causes and solutions to overcome the deterioration in the quality of education in Indonesia.

Macro perspective many factors that influence the quality of education, including curriculum factors, educational policies, educational facilities, application of information and communication technology in the world of education, especially in teaching and learning activities, application of methods, strategies and approaches to education that are current and modern, educational evaluation methods education, adequate education costs, professionally managed education management, human resources of education practitioners who are trained, knowledgeable, experienced and professional (MS Saggaf, Nasriyah, et al., 2018; MS Saggaf et al., 2017; Salam, Akib, \& Daraba, 2018). To find out the Management Function in Improving the Quality of Education Services in Biak Kota 1 High School, the researchers used Fayol's theory (1916) to divide four basic functions of management, namely Planning (Organizing), Organizing, Commanding (Coordination), Coordinating (Coordination), controlling. These five management functions are abbreviated as POCCC, which are broadly presented as follows.

Planning. Planning is planning the selection of facts and linking the facts and making and using estimates or assumptions for the future by describing and formulating the activities needed to achieve the desired results. And the ability to visualize and look forward is needed to formulate a set of actions for the future. Planning also includes the manager's function related to choosing goals, policies, procedures, programs and alternatives.

Based on the planning function above to find out that an interview has been conducted with the deputy headmaster in charge of facilities and infrastructure (Interview on July 15, 2019 at 10:30 Eastern Indonesia Time), he stated that: 
"The planning function in improving the quality of education here is usually in improving the quality of lessons, we have a meeting which is usually called a workshop. The workshop involved all stakeholders of SMAN 1 Biak, both the school principal, deputy headmaster teachers and the cleaning and security guards. Where in the workshop we discussed the evaluation of the last school year if there was a shortage of the past school year it would be completed in the new school year and preparing a new school year. Then do the distribution of tasks and responsibilities to other teachers ".

To find out the planning function, an interview with the Vice-Principal of the Student Affairs (Interview on July 17, 2019 at 11.42 Central Indonesian Time), he stated that:

"For our planning function, before starting the new school year, it usually starts with a workshop first, so the workshop contains activities where we plan school activities for one school year. Starting with the division of tasks by the principal of the school for us ladies and gentlemen by our respective functions and the division of teaching assignments for us ladies and gentlemen and other workloads outside of our duties as subject teachers. Everything is planned in the form of a workshop. Then we also the teachers have to make our work programs. For example the deputy headmaster for facilities and infrastructure made procurement such as chairs and benches for this new school year and whether some chairs and tables had to be replaced or repaired. The deputy headmaster of the student section determines what kind of contests students must participate in and prepares these students to take part in the competition ".

To find out the planning function, an interview with the Vice-Principal of the Curriculum Section, Abdul Rahman, S.Pd. (Interview on 19 July 2019 at 10.42 Central Indonesia Time), he stated that:

"For the planning function, it is usually discussed at the time of the workshop, the workshop was a meeting held before the start of the new school year. The workshop usually discusses the planned activities that will be carried out in the new school year, and evaluates how the previous school year had any shortcomings and obstacles encountered, so that the new school year can be completed and maximized again. Then do the distribution of tasks and responsibilities to stakeholders such as the division of homeroom teachers and subject teachers. Also there will be a division of tasks outside the duties and responsibilities that have been given all that to improve the quality of service to our students ".

Planning is the initial stage in the activity and most importantly where activities are defining organizational goals, making strategies, and developing organizational work plans. From the results of interviews at the SMAN 1 Biak school the authors concluded that the Planning Function in Improving the Quality of Education Services at SMAN 1 Biak, in the planning process was carried out well, which carried out an evaluation of the performance that had been carried out in the last school year and involved all stakeholders who were in SMAN 1 Biak so that it can overcome the deficiencies and obstacles that exist so that the planning process can be by the initial plan.

Organizing. Organizing is the determination, grouping and compilation of various types of activities needed to achieve activities, placement of people (employees) on the activities of physical provision suitable for work needs and extension of authority relationships delegated to each person about the implementation of activities which is expected. Based on the opinion 
340 Jurnal Ilmiah Ilmu Administrasi Publik: Jurnal Pemikiran dan Penelitian Administrasi Publik Volume 9 Number 2, July- December 2019. Page 335-344

above, this organizing function covers all management activities that are manifested in the structure of duties and authority. Organizing regulates activities that must be carried out by organizational units such as the delegation of authority to carry out work.

Based on the organizing function above to find out that an interview with the Deputy Principal facilities and infrastructure (Interview on 15 July 2019 at 10.30 Eastern Indonesia Time), he stated that:

"For organizing the implementation of this task, there must be a part of each stakeholder. There are three deputy principals, each of whom has their task of the curriculum principal to make a lesson schedule, the vice-principal of students for the preparation of students who will participate in competitions. Deputy Principal facilities and infrastructure maximizing the existing facilities and infrastructure. As well as the distribution of homeroom teachers, those who become homeroom teachers are prioritized who are already Civil Servants (PNS), because it involves signatures, ladder sign must have an Employee Registration Number, but if the number of teachers who are PNS is less then it will only be filled with honours.

To find out the planning function, an interview was conducted with the Vice-Principal of Student Affairs, Vanda Fransisca Putuhena, S.Pd. (Interview on July 17, 2019 at 11.42 Eastern Indonesia Time), he stated that:

"For our coordination, all the doors are coordinated through the principal, so every plan and agenda of activities we make is returned to the principal to ask for his opinion and approval, if agreed, we will implement it, otherwise we will look for other plans".

To find out the planning function, an interview with the Vice-Principal of the Curriculum (Interview on July 19, 2019 At 10.42 Eastern Indonesia Time), he stated that:

"For the organizing function itself, each stakeholder has been given their respective duties and responsibilities, but it does not rule out the possibility to coordinate with other teacher friends in carrying out these tasks and responsibilities. For example, some stakeholders do not understand the tasks assigned to them, these stakeholders can coordinate with other teachers who better understand the task ".

Organizing is the division of tasks given to each employee, who after getting the results of the plan that has been determined previously. From the results of interviews at the Biak 1 Senior High School, the researchers concluded that the organizing function had gone well, as evidenced by the time of field observations of coordination between teachers.

Commanding. Commanding can be done to provide direction to all workers so that they want to cooperate and can work effectively in achieving a company's goals. In this management function, guidance is given to workers in the form of motivation, leadership and also communication to carry out their duties properly and by established goals. The principle of direction also has the goal of being able to adjust one's goals to the goals of an organization that will be formed into a common goal. Therefore, the direction of the management function according to Henry Fayol is intended to provide direction on an organization to Human Resources (HR), which incidentally is the executor of the organization or company to be able to complete their tasks properly. 
Based on the briefing function above to find out that an interview with the Deputy Principal facilities and infrastructure (Interview on 15 July 2019 at 10.30 Eastern Indonesia Time), he stated that:

"For the actual briefing function, we follow an order which will then be coordinated with the school principal, the school principal will provide direction. We ask for opinions and direction from the principal to carry out their respective duties".

To find out the briefing function, an interview was conducted with the Deputy Head of Central Indonesia Time), he stated that:

"The briefing function is all one direction door which is sourced from the principal, the principal who gives general direction to us then we each translate according to our respective functions and responsibilities".

To find out the briefing function, an interview was conducted with the Vice Principal of the Curriculum (Interview on 19 July 2019 at 10.42 Eastern Indonesia Time), he stated that: "For the briefing function, all directions sourced from our school principal only carry out according to the instructions and directions that the principal gives us about plans and work agendas".

Directing is a management function that is related to the effort of giving guidance, suggestions, instructions, so that the task can be carried out properly and is truly aimed at what was originally set. From the results of interviews at the SMAN 1 Biak school, the researchers concluded that the commanding function had gone well but at the time of observation the Principals were often on duty out of town, so the commanding given was not optimal.

Coordinating. Coordinating is the integration, integration, synchronization of the efforts of group members to provide unity of action in pursuit of common goals. This is a hidden power that binds all other functions of management. Coordination can keep the activities of an organization continue to synergize and can also work well together. Not only that, but communication is also very needed in the process of coordination between lines in the organization, both in formal and informal communication. Coordination cannot be separated from management because achieving alignment between individual efforts towards achieving group goals is the key to management's success. Coordination is the essence of management and is implicit and inherent in all management functions.

Based on the organizing function above to find out that an interview had been conducted with the Vice-Principal facilities and infrastructure (Interview on 15 July 2019 at 10.30 Eastern Indonesia Time), he stated that:

"For clear coordination between one another, coordinate with each other so that they can complement each other. For example, we lack understanding of a part, we share with other teachers who understand it so we can go according to plan. Still each carries out the tasks and responsibilities given but coordination is important ".

To find out the briefing function, an interview with the Vice-Principal of the Student Affairs (Interview on July 17, 2019 at 11.42 Eastern Indonesia Time), he stated that:

"For coordination, it is related to the arrangement of structures for determining activities to achieve the agreed goals. Classification of activities, assignments, a delegation of authority or duties to carry out work among stakeholders ".

To find out the organizing function of an interview with the Vice-Principal of the Curriculum section (Interview on 19 July 2019 at 10.42 Eastern Indonesia Time), he stated that: 


\section{Jurnal Ilmiah Ilmu Administrasi Publik: Jurnal Pemikiran dan Penelitian Administrasi Publik Volume 9 Number 2, July- December 2019. Page 335-344}

"Our organizing functions carry out the tasks and responsibilities that have been given but not all can do or understand the tasks so there is usually coordination between stakeholders".

Coordinating is one of the management functions to carry out various activities to avoid chaos, disagreement, voiding of activities, by connecting, integrating and aligning the work of subordinates so that there is directed cooperation in efforts to achieve common goals or organizational goals. From the results of interviews at the SMAN 1 Biak school, the researchers concluded that the organizing function had been going well and the results of the organizational observations being carried out were good enough that the stakeholders quite understood their duties and responsibilities.

Controlling. Controlling is the process of determining what will be achieved (standard), what is being done (implementation), assessing implementation, and if necessary taking corrective action so that implementation can proceed according to plan, i.e., by standards. Or in other words, supervision is an activity related to controlling or supervising every work and taking corrective actions.

Based on the control function above to find out that an interview has been conducted with the Deputy Principal facilities and infrastructure (Interview on 15 July 2019 at 10.30 Eastern Indonesia Time), he stated that:

"The control function is usually that each work program and the tasks assigned are monitored for performance, a work report is prepared and the report must be clear so that it can be accounted for. So the control through checking the results of the work report by what is not done can be justified or not".

To find out the control function has been conducted an interview with the Deputy Principal Student Affairs (Interview on July 17, 2019 At 11.42 Eastern Indonesia Time), he stated that: "For the control function, we all work together to be able to practice school policies whose function is to improve the quality of education in SMAN 1 Biak".

To find out the control function, an interview was conducted with the Deputy Principal of the Curriculum Section Abdul Rahman, S.Pd. (Interview on 19 July 2019 at 10.42 Eastern Indonesia Time), he stated that:

"The control function is usually in the form of a report of the tasks and responsibilities that have been given, all activities must end with a report of accountability so that it can be a form of oversight to stakeholders outside the rules or policies that need to be followed".

Control is a way or a tool to ensure that the planning and organizing and mobilization that has been carried out goes to what has been previously determined. From the results of interviews at SMAN 1 Biak researchers the researchers concluded that the implementation of the control function at SMAN 1 Biak could not be said to be good due to lack of control over teachers and the level of discipline that was still low. From the management function above, the Quality of Education Service at SMAN 1 Biak is outlined, the following questions are asked, how is the quality of education services and how is the strategy to improve the quality of education services at SMAN 1 Biak? 
Based on questions in improving the quality of education services and to find out interviews with the Vice-Principal facilities and infrastructure (Interview on 15 July 2019 at 10.30 Eastern Indonesia Time), he stated that:

"To improve the quality of our education services from SMAN 1 Biak, we have tried our best to serve students, but judging from the results of our services that the value of others, for example the community, parents, but we have tried our best and for strategies in improving the quality of our education services. Mentioning evaluation, we evaluate every obstacle faced and tried as much as possible to fix it and ask for advice and input from the community to overcome the obstacles that we face ".

Based on questions in improving the quality of education services and to find out interviews with the Deputy Principal of the Student Affairs (Interview on July 17, 2019 at 11.42 Eastern Indonesia Time), he stated that:

"For the quality of education services there must be indicators that are seen, I take the example of indicators of student graduation rates for the graduation level of SMAN 1 is always $100 \%$. Since I teach here the graduation rate is always $100 \%$ and for the strategy that we do is the vision and mission of our school, from the vision and mission we try our best to make it happen. Because the vision and mission are what we want to realize in this school, therefore the strategy used is trying to realize the vision and mission."

Based on questions in improving the quality of education services and to find out interviews with the Vice-Principal of the Curriculum Section Abdul Rahman, S.Pd. (Interview on 19 July 2019 at 10.42 Eastern Indonesia Time), he stated that:

"For the quality of education services that we provide can be said to be maximum. It can be seen from the number of new students always increasing and we are also trying to improve services further. For our strategy, it is in the form of maximizing existing facilities and infrastructure, and we always review the constraints faced and find a solution as soon as possible".

From the interview results above, the authors conclude that efforts to improve the quality of education services and strategies to improve the quality of education services in SMAN 1 Biak namely the quality of educational services are maximum and the strategy implemented is to evaluate the performance of teachers and further improve performance as much as possible and try to vision and mission can be realized and implemented.

\section{CONCLUSION}

Management functions are applied based on the stages in the management process including planning, organizing, directing, coordinating, controlling. This is by what happened at SMAN 1 Biak school. At these stages the SMAN 1 Biak school in the process divides the stages based on school conditions. As explained by the interviewees at SMAN 1 Biak regarding management functions, the implementation of management functions must be by the management process itself, namely Planning, organizing, commanding, coordinating and controlling. It can be concluded that the implementation of the management functions of SMAN 1 Biak is classified as good, as evidenced by the fulfillment of all activities in the process of implementing management functions. 
344|Jurnal Ilmiah Ilmu Administrasi Publik: Jurnal Pemikiran dan Penelitian Administrasi Publik Volume 9 Number 2, July- December 2019. Page 335-344

\section{REFERENCES}

Akib, H., Guntur, M., \& Salam, R. (2016). Civitas Academic Perception of "Blissful Services" for Recipient Postgraduate Program State University of Makassar, Indonesia. International Conference on Public Organization VI (ICONPO VI), 340-350. Thammasat University, Tha Prachan Campus.

Amanda, M. O., Salam, R., \& Saggaf, S. (2017). Pengaruh Supervisi Kepala Sekolah Terhadap Kinerja Guru Di SMK Negeri 1 Bungoro Kabupaten Pangkep. Prosiding Seminar Nasional Himpunan Sarjana Ilmu-Ilmu Sosial, 2, 149-154.

Creswell, J. W., \& Creswell, J. D. (2017). Research design: Qualitative, quantitative, and mixed methods approach. Sage publications.

Creswell, J. W., \& Poth, C. N. (2018). Qualitative inquiry Research Design Choosing Among Five Approaches (Vol. 53). https://doi.org/10.1017/CBO9781107415324.004

Fayol, H. (1916). General principles of management. Classics of Organization Theory, 2, 15.

Saggaf, M. S., Akib, H., Salam, R., Baharuddin, A., \& Kasmita, M. (2018). The Quality Analysis Of Academic Services.

Saggaf, M. S., Aras, M., Akib, H., Salam, R., Baharuddin, A., \& Kasmita, M. (2018). The Quality Analysis of Academic Services Based on Importance Performance Analysis (IPA).

Saggaf, M. S., Nasriyah, N., Salam, R., \& Wirawan, H. (2018). The Influence of Teacher's Pedagogic Competence on Learning Motivation of Student of Office Administration Expertise Package.

Saggaf, M. S., \& Salam, R. (2017). Examining Academic Service using Importance Performance Analysis (IPA).

Saggaf, M. S., Salam, R., \& Rifka, R. (2017). The Effect of Classroom Management on Student Learning Outcomes. International Conference on Education, Science, Art and Technology, 98-102.

Saggaf, S., Salam, R., Kahar, F., \& Akib, H. (2014). Pelayanan Fungsi Administrasi Perkantoran Modern. Jurnal Ad'ministrare, 1(1), 20-27.

Salam, R. (2015). Penerapan Fungsi Administrasi Perkantoran Modern berbasis Daya Saing Organisasi dalam menyongsong MEA 2015. SEMINAR NASIONAL "Revolusi Mental Dan Kemandirian Bangsa Melalui Pendidikan Ilmu-Ilmu Sosial Dalam Menghadapi MEA 2015” Himpunan Sarjana Pendidikan Ilmu-Ilmu Sosial Indonesia, 1, 186-190.

Salam, R., Akib, H., \& Daraba, D. (2018). Utilization of Learning Media In Motivating Student Learning. 1st International Conference on Social Sciences (ICSS 2018). Atlantis Press.

Salam, R., Rosdiana, Suarlin, \& Akib, H. (2014). The Impact Of Policy on Region Expansion to Office Administrative Services in Barombong Subdistrict of Gowa District. International Conference on Mathematics, Sciences, Technology, Education and Their Applications, 1(1), 505. The State University of Makassar.

Terry, G. R., \& Franklin, S. G. (1968). Principles of management. RD Irwin. 